\title{
Effect of Using Ultrapure Dialysate for Hemodialysis on the Level of Circulating Bacterial Fragment in Renal Failure Patients
}

\author{
Bonnie Ching-Ha Kwan Kai-Ming Chow Terry King-Wing Ma \\ Phyllis Mei-Shan Cheng Chi-Bon Leung Philip Kam-Tao Li Cheuk-Chun Szeto \\ Department of Medicine, Prince of Wales Hospital, The Chinese University of Hong Kong, Hong Kong, SAR, China
}

\section{Key Words}

Renal failure · Cardiovascular disease · Survival

\begin{abstract}
Background: Cardiovascular disease is the major cause of mortality and morbidity in dialysis patients. Recently, circulating endotoxin is found to associate with the systemic inflammatory state and cardiovascular disease of dialysis patients. Previous studies showed that the use of ultrapure dialysate for hemodialysis could reduce the exposure to exogenous endotoxin. We studied the effect of using ultrapure dialysate for hemodialysis on circulating endotoxin and bacterial DNA fragment levels and vascular stiffness. Methods: This is an open-labeled prospective study of 25 patients (14 male). Circulating endotoxin and bacterial DNA level, vascular stiffness as represented by arterial pulse wave velocity (PWV), nutrition and hydration status were monitored before and repeatedly throughout 12 months after the use of ultrapure dialysate for hemodialysis. Results: The average age was $58.9 \pm 10.2$ years; 21 patients completed the study. Within 4 weeks of conversion to ultrapure dialysate for hemodialysis, the plasma endotoxin level fell from $0.302 \pm$ 0.083 to $0.209 \pm 0.044 \mathrm{EU} / \mathrm{ml}(p<0.0001)$ and then remained static, while serum bacterial DNA level remained similar. Fur-
\end{abstract}

thermore, the time-averaged plasma endotoxin level during the study period significantly correlated with serum C-reactive protein level $(r=0.483, p=0.017)$, carotid-femoral PWV $(r=0.455, p=0.033)$, and malnutrition inflammation score $(r=0.461, p=0.031)$. The time-averaged serum bacterial DNA level significantly correlated with malnutrition inflammation score $(r=0.550, p=0.008)$ and inversely with subjective global assessment score $(r=-0.543, p=0.009)$, but not with PWV. Conclusions: In hemodialysis patients, circulating endotoxin level is associated with vascular stiffness and systemic inflammation. Using ultrapure dialysate for hemodialysis effectively reduces circulating endotoxin level in hemodialysis patients. The long-term benefit of using ultrapure dialysate for hemodialysis requires further study.

(c) 2013 S. Karger AG, Basel

\section{Introduction}

Patients with chronic kidney disease (CKD) are at high risk of developing cardiovascular disease (CVD) $[1,2]$. Longitudinal studies have established that CVD events occur more frequently than renal events in $\mathrm{CKD}$, and CVD mortality rates are in fact higher than the rates of reaching end-stage renal disease [3]. CVD shares many

\section{KARGER}

E-Mail karger@karger.com

www.karger.com/nec
(C) 2013 S. Karger AG, Basel

$1660-2110 / 13 / 1234-0246 \$ 38.00 / 0$
Dr. C.C. Szeto

Department of Medicine and Therapeutics, Prince of Wales Hospital

Chinese University of Hong Kong

Shatin, NT, Hong Kong, SAR (China)

E-Mail ccszeto@ cuhk.edu.hk 
similar risk factors with $\mathrm{CKD}$, such as diabetes and hypertension [4]. However, after accounting for traditional risk factors, CKD remains an independent risk factor for CVD [5]. It is now recognized that systemic inflammation plays a key role in atherosclerosis [6] and is an important contributor to CVD morbidity and mortality in CKD patients [7].

Around $30-50 \%$ of CKD or dialysis patients have serological evidence of an activated inflammatory response [8-10]. However, the principal underlying causes of immune activation in CKD remains elusive. There is recent evidence that circulating microbial products, probably derived from the gastrointestinal tract, could be found in considerable amount in CKD patients, and endotoxemia may have a contributory role to the systemic inflammatory state and accelerated atherosclerosis in dialysis patients $[11,12]$.

The situation of endotoxemia becomes more complicated in hemodialysis. During the course of a hemodialysis session, the patient's blood comes in contact with 80160 liters of dialysate through the dialysis membrane. Consequently, the purity of the dialysate and the permeability of the membrane for dialysate contaminants (i.e. exogenous bacterial endotoxin from the municipal water supply and, more importantly, bacterial biofilms in the dialysis water storage and distribution system) might contribute in part to the triggering of systemic inflammatory response that afflict hemodialysis patients. In recent years, the maximum limit of bacterial and endotoxin contamination in dialysate has been reduced. For the currently recommended ultrapure dialysate, the Association for the Advancement of Medical Instrumentation introduced a bacterial count limit of less than $0.1 \mathrm{CFU} / \mathrm{ml}$ and an endotoxin level of less than $0.03 \mathrm{EU} / \mathrm{ml}$, which is identical to the detection limit provided by the commonly used Limulus amebocyte lysate assay [13]. The use of an ultrapure dialysate results in a reduction in dialysate endotoxin level, and is reported to reduce inflammatory responses in hemodialysis patients, such as the increase in plasma levels of C-reactive protein (CRP), interleukin-6, and $\beta_{2}$-microglobulin [14-17]. However, the detection of biologically relevant contaminants can be missed when applying the recommended standard detection methods of bacterial culture and endotoxin assay [18]. The effects of ultrapure dialysate on the endogenous circulating level of bacterial fragments in hemodialysis patients have not been evaluated. In the present study, we compare the circulating levels of bacterial fragments and before and after using ultrapure dialysate for hemodialysis.

Ultrapure Dialysate for HD

\section{Patients and Methods}

This is a prospective open-label single arm study of 25 longterm hemodialysis patients. Inclusion criteria were: (1) age between 18 and 75 years; (2) on hemodialysis treatment with conventional bicarbonate dialysate for at least 3 months; (3) no major change in dialysis prescription for at least 3 months preceding enrolment; (4) vascular access functioning properly, and (5) signed informed consent available. We excluded patients with chronic hepatitis $\mathrm{B}$ or $\mathrm{C}$ infection, those with other active or chronic infection, inflammatory disease, or on-going malignancy, patients receiving immunosuppressive medications, and those with planned living-donor renal transplantation within 1 year.

\section{Study Procedure}

Study eligibility was determined at a screening visit and confirmed at a qualifying visit 4 weeks later. Baseline assessments included a review of the medical history and physical examination. After written informed consent, ultrapure dialysate (instead of conventional water treated with reverse osmosis) was used for hemodialysis by the implementation of DIASAFE-plus ultrafilters (Fresenius Medical Care, Bad Homburg, Germany) within the fluid pathway of the dialysis machine. Water treatment of our unit was performed by the Hemodialysis Water Treatment Plant (with reverse osmosis) of AQUABOSS ${ }^{\circledR}$, Model ECORO DIA II by Lauer Membran Wassertechnik, GmbH, Germany. As part of our routine clinical practice, dialysate endotoxin level and bacterial count were monitored every 3 months. Besides the dialysis fluid, all patients will otherwise be dialyzed with their usual prescriptions (dialyzer, blood flow, dialysate flow, and dialysis time) and the dialysis prescription was kept unchanged during the 12-month study period unless a change was required for medical reasons.

Clinical and laboratory evaluations were then assessed monthly for 12 months. Clinical evaluations included blood pressure, and body weight. Laboratory tests include blood tests for complete blood counts, serum electrolytes, urea, creatinine, and liver enzymes. Serum endotoxin and bacterial DNA levels were measured at $-1,0,3,6,9$ and 12 months. Nutritional assessment was performed at 0,6 and 12 months. All patients received their usual antihypertensive therapy, with an aim to keep the target blood pressure below 130/80 $\mathrm{mm} \mathrm{Hg}$.

\section{Circulating Endotoxin Level}

The method of plasma endotoxin quantification has been described previously [11]. Briefly, plasma samples were diluted to $20 \%$ with endotoxin-free water and then heated to $70^{\circ} \mathrm{C}$ for $10 \mathrm{~min}$ to inactivate plasma proteins. We then quantified plasma endotoxin with a commercially available Limulus amebocyte assay (Cambrex, Verviers, Belgium) according to the manufacturer's protocol. The detection limit of this assay was $0.01 \mathrm{EU} / \mathrm{ml}$. Samples with endotoxin level below the detection limit were taken as $0 \mathrm{EU} /$ $\mathrm{ml}$. All samples were run in duplicate and background subtracted.

\section{Circulating Bacterial DNA Level}

DNA from 200- $\mu$ l aliquots of EDTA-treated whole blood and dialysis fluid was extracted using the EZ1 DNA tissue kit and BioRobot EZ1 with the EZ1 bacteria card (Qiagen), according to the manufacturer's instructions. Purified DNA was eluted in $50 \mu \mathrm{l}$ of elution buffer before amplification. The method of bacterial DNA amplification has been described previously [19]. Briefly, 
universal primers used for polymerase chain reaction (PCR) amplification of the bacterial $16 \mathrm{~S}$ rRNA gene will be p16SrRNA+ and p16SrRNA-, which are able to amplify DNA from either Grampositive or Gram-negative bacteria. Aliquots of $20-\mu \mathrm{l}$ DNA samples were used for amplification in a $50-\mu$ PCR reaction mixture containing (final concentration) $67 \mathrm{mM}$ Tris $\mathrm{HCl}(\mathrm{pH} 8.8), 16 \mathrm{mM}$ (NH4) ${ }_{2} \mathrm{SO}_{4}, 200 \mu \mathrm{M}$ dNTPs, $3.5 \mathrm{mM} \mathrm{MgCl}_{2}, 25$ pmol of each primer, and $1 \mathrm{U}$ Taq polymerase (GoTaq DNA polymerase, Promega, Madison, Wisc., USA), by using the following thermal conditions: initial denaturation of $95^{\circ} \mathrm{C}$ for $5 \mathrm{~min}$; then 40 cycles of $95^{\circ} \mathrm{C}$ for $45 \mathrm{~s}, 53^{\circ} \mathrm{C}$ for $1 \mathrm{~min}$, and $72^{\circ} \mathrm{C}$ for $1 \mathrm{~min}$ and $30 \mathrm{~s}$, and a final extension step of $72^{\circ} \mathrm{C}$ for $10 \mathrm{~min}$. When no detectable level of a transcript was found (defined as no detectable level after 40 cycles of RT-QPCR) and there was zero value, a value equal to half of the minimum observed gene expression level was assigned [20]. All samples were run in triplicates. Since plasma was directly used as the template and there is no intrinsic housekeeping gene for comparison, the number of PCR cycles at which bacterial DNA could be detected is reported.

\section{Nutritional Assessment}

Nutritional status was assessed by the subjective global assessment (SGA) score, the comprehensive malnutrition-inflammation score, measurement of mid-arm circumference, and body composition. The 4-item 7-point SGA scoring system was used [21]. Calculation of the malnutrition inflammation score has been described previously [22]. Mid-arm circumference was measured by conventional methods. Body composition was assessed by the Body Composition Monitor (Fresenius Medical Care). Briefly, electrodes were attached to one hand and one foot with the patient in a supine position. After the patient cable was connected, the measurement would complete automatically in $2 \mathrm{~min}$. We then computed the following parameters from this test: volume of over hydration, intracellular water, and extracellular water.

Pulse Wave Velocity Study

Pulse wave velocity (PWV), an index of aortic stiffness, was measured at 0,6 and 12 months using an automatic computerized recorder and the results are analyzed using the Complior ${ }^{\circledR}$ SP program (Artech Medical, France). The method of PWV measurement has been described previously [23]. Briefly, pressure-sensitive transducers were placed over the neck (carotid artery), wrist (radial artery) and groin (femoral artery) with the patient in the supine position within 1 week of PET. PWV of the carotid-femoral and carotid-radial territory was calculated by dividing the distance between the sensors by the time corresponding to the period separating the start of the rising phase of the carotid pulse wave and that of the femoral and also the radial pulse waves. The test was performed by the same observer.

\section{End Points}

The primary end-point of this study was the change in circulating endotoxin and bacterial DNA levels. Secondary end points included the change in nutritional status, body composition, and arterial pulse wave velocity.

\section{Statistical Analysis}

Statistical analysis was performed by SPSS for Windows software version 15.0 (SPSS Inc., Chicago, Ill., USA). Data were expressed in mean \pm SD unless otherwise specified. Normal distribu-
Table 1. Baseline clinical characteristics

\begin{tabular}{lc}
\hline Number of patients & 25 \\
Sex, M/F & $14 / 11$ \\
Age, years & $60.4 \pm 10.3$ \\
Body height, cm & $158.0 \pm 7.8$ \\
Duration of dialysis, months & \\
$\quad$ Total & $114.4 \pm 65.3$ \\
$\quad$ On hemodialysis & $72.6 \pm 47.6$ \\
Diagnosis, n (\%) & \\
$\quad$ Glomerulonephritis & $8(32)$ \\
$\quad$ Diabetes & $10(40)$ \\
$\quad$ Hypertension & $1(4)$ \\
$\quad$ Obstruction & $1(4)$ \\
$\quad$ Others/unknown & $5(20)$ \\
Major comorbidity, n (\%) & \\
$\quad$ Diabetes & $11(44)$ \\
Coronary heart disease & $7(28)$ \\
Cerebrovascular disease & $4(16)$ \\
Charlson's comorbidity score & $5.2 \pm 2.1$
\end{tabular}

tion of data was checked by the Shapiro-Wilk test. Data between groups were compared by the $\chi^{2}$ test, Student's t test, or Person's correlation coefficient as appropriate. Longitudinal change of circulating endotoxin level and other clinical parameters were compared by analysis of variance for repeated measures. To explore the effect of circulating bacterial fragment on nutrition and inflammatory status, we computed the time-average plasma endotoxin and serum bacterial DNA levels during the study period for subsequent correlation analysis. $\mathrm{p}<0.05$ was considered statistically significant. All probabilities were two-tailed.

\section{Results}

We studied 25 chronic hemodialysis patients. The baseline data are summarized in table 1. All patients were anuric. The dialyzer used were Fresenius Polysulfone ${ }^{\circledR}$ FX10 (12 cases), FX8 (5 cases), FX 80 (4 cases) (all from Fresenius Medical Care) and Poliflux 17-liter dialyser (Gambro Lundia AB, Sweden) (4 cases). During the study period, 3 patients died, and another patient withdrew consent. After 1 year, 21 patients completed the study.

\section{Circulating Endotoxin and Bacterial DNA Levels}

The plasma endotoxin and serum bacterial DNA levels during the study period are summarized in figure 1 . Within 4 weeks of conversion to ultrapure dialysate for hemodialysis, the plasma endotoxin level fell from 0.302 \pm 0.083 to $0.209 \pm 0.044 \mathrm{EU} / \mathrm{ml}(\mathrm{p}<0.0001)$ and then remained static. The baseline serum bacterial DNA level was $33.8 \pm 1.1$ cycles. Although there was a statistically 
Table 2. Biochemical, nutrition and inflammatory indices during the study period

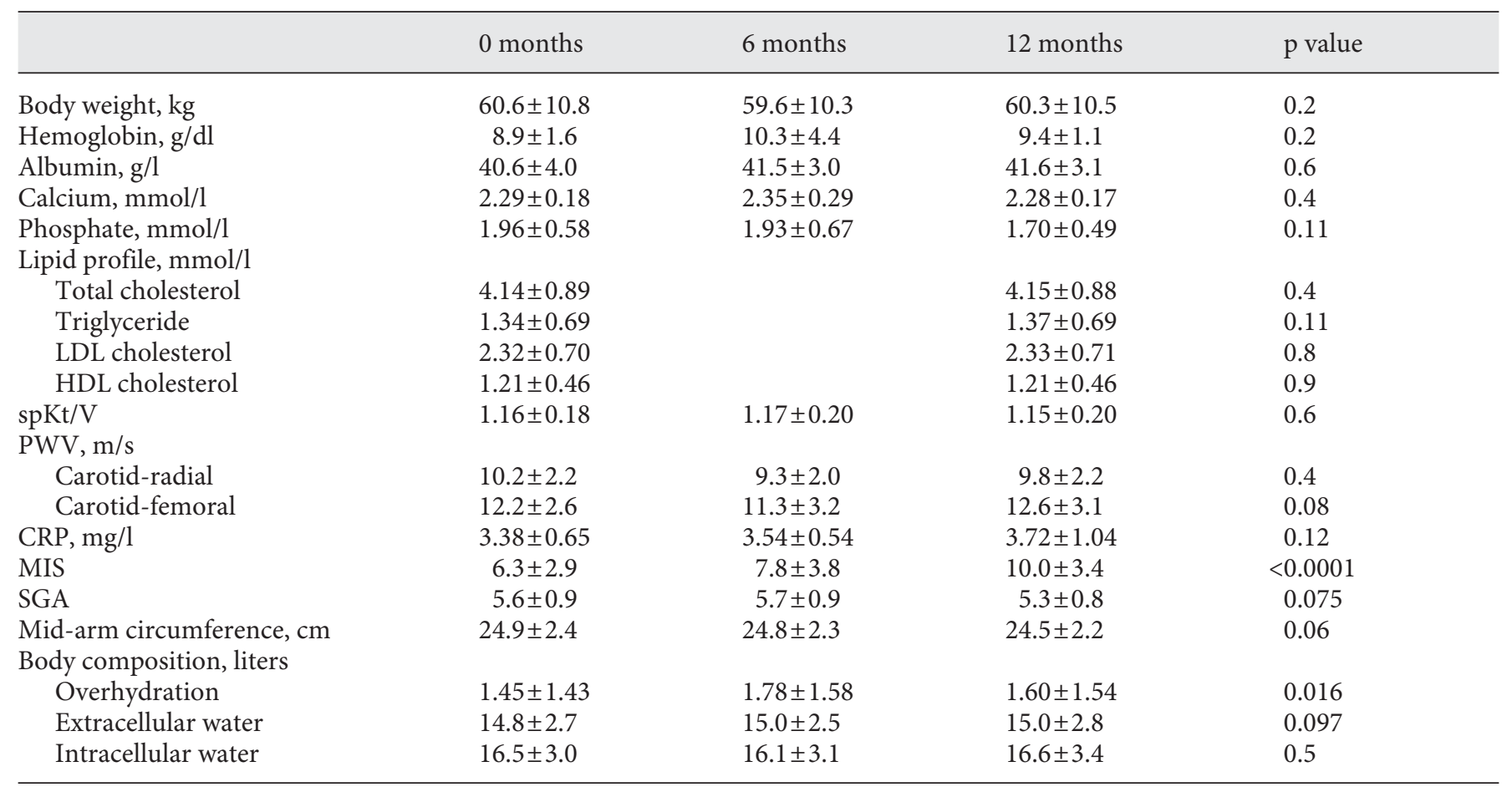

$\mathrm{LDL}=\mathrm{Low}$-density lipoprotein; $\mathrm{HDL}=$ high-density lipoprotein; spKt/V = single pool Kt/V; $\mathrm{MIS}=$ malnutrition inflammation score; $\mathrm{SGA}=$ subjective global assessment score. Data were compared by the paired Student's t test or analysis of variance (ANOVA) for repeated measures.
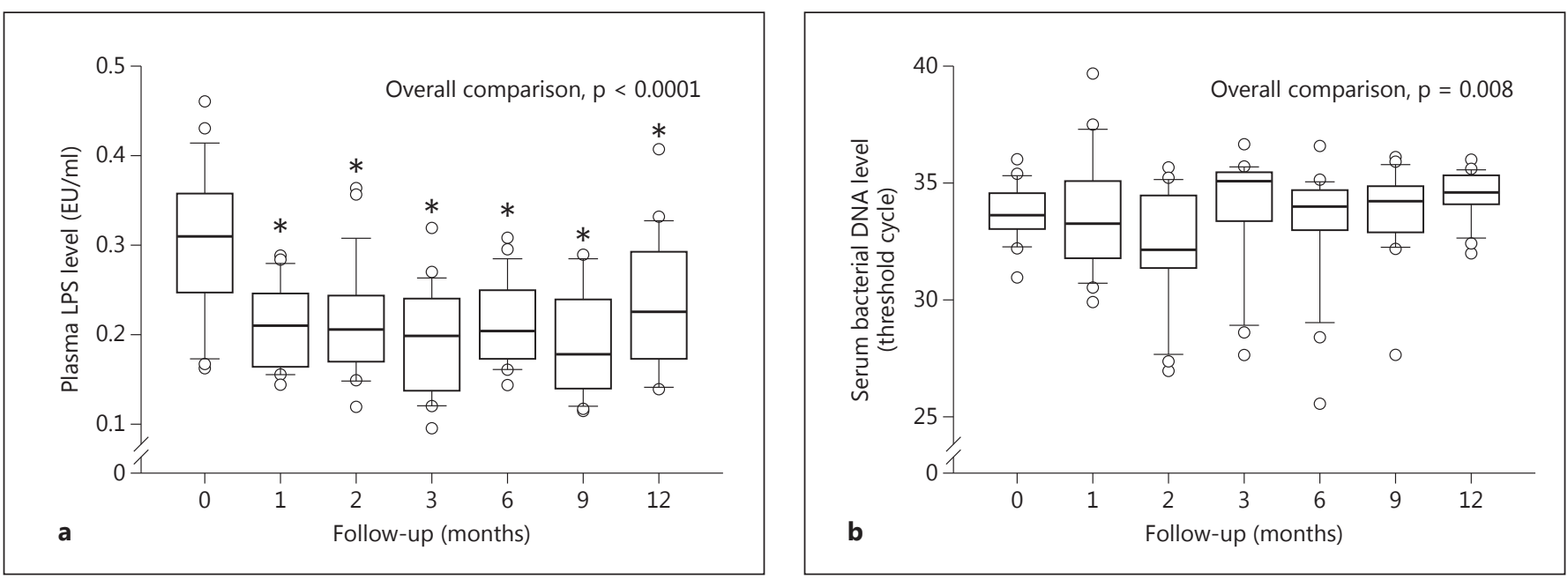

Fig. 1. Circulating bacterial fragment levels during the study period. a Plasma endotoxin level. b Serum bacterial DNA level. The p values of overall comparison are computed by analysis of variance for repeated measures. Asterisks depict a significant difference from baseline level by post hoc analysis. 
Fig. 2. Relation between the time-averaged plasma endotoxin level and serum albumin (a); serum CRP level (b); carotid-femoral pulse wave velocity (c), and malnutrition inflammation score (d). Data are compared by Pearson's correlation coefficient.

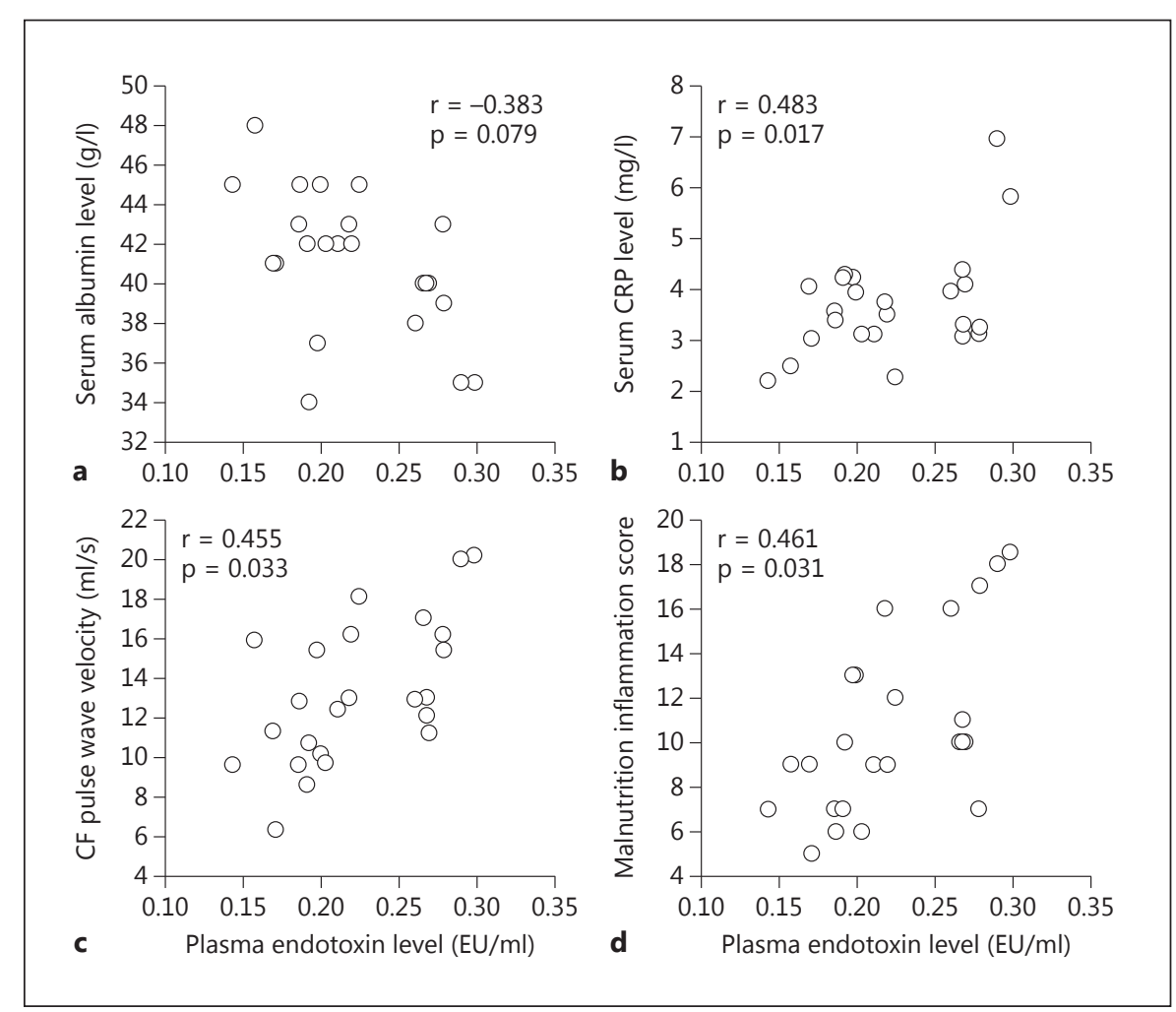

significant fluctuation in serum bacterial DNA level during the study period, post hoc analysis showed that none of the time points had significant difference with the baseline level. At baseline, plasma endotoxin level significantly correlated with serum bacterial DNA level $(r=0.522$, $\mathrm{p}=0.007)$. However, this correlation disappeared during the follow-up period, after ultrapure dialysate was used for hemodialysis. The time-averaged plasma endotoxin and serum bacterial DNA levels were $0.224 \pm 0.045 \mathrm{EU} /$ $\mathrm{ml}$ and $33.6 \pm 1.0$ cycles, respectively, and the two had no significant correlation $(\mathrm{r}=0.042, \mathrm{p}=0.8)$.

Baseline biochemical, nutritional and inflammatory statuses are summarized in table 2. During the study period, there was no significant change of serum CRP level $(3.38 \pm 0.65,3.54 \pm 0.54$, and $3.72 \pm 1.04 \mathrm{mg} / \mathrm{l}$ at 0,6 and 12 months, respectively, $\mathrm{p}=0.12$ ). Baseline plasma endotoxin level significantly correlated with serum CRP level $(\mathrm{r}=0.409, \mathrm{p}=0.042)$ and carotid-femoral PWV $(\mathrm{r}=$ $0.414, \mathrm{p}=0.040$ ), while baseline serum bacterial DNA level correlated with carotid-femoral PWV $(\mathrm{r}=0.412$, $\mathrm{p}=0.041)$, overall SGA score $(\mathrm{r}=0.407, \mathrm{p}=0.043)$, and serum CRP level $(r=0.351, p=0.086)$, although the last correlation did not reach statistical significance.

\section{Biochemical, Nutrition and Inflammatory State}

The biochemical, nutritional and inflammatory status during the study period are also summarized in table 2 . In essence, there were significant increases in the comprehensive malnutrition inflammation score and the degree of overhydration amongst the patients over 1 year. On the other hand, there was no significant change in carotidfemoral pulse wave velocity, serum CRP level, extracellular water volume, SGA score, or mid-arm circumference during the study period. There was no significant change in the usage of recombinant human erythropoietin amongst the patients (details not shown).

The time-averaged plasma endotoxin level during the study period correlated with serum CRP level $(r=0.483$, $\mathrm{p}=0.017)$, carotid-femoral PWV $(\mathrm{r}=0.455, \mathrm{p}=0.033)$, and malnutrition inflammation score $(\mathrm{r}=0.461, \mathrm{p}=$ 0.031 ) (fig. 2). In contrast, the time-averaged serum bacterial DNA level significantly with malnutrition inflammation score $(\mathrm{r}=0.550, \mathrm{p}=0.008)$, and inversely correlated with the subjective global assessment score at 12 months $(r=-0.543, p=0.009)$. Further analysis showed that the time-averaged serum bacterial DNA level inversely correlated with the weight change $(\mathrm{r}=-0.521, \mathrm{p}=$ $0.013)$, subcutaneous fat $(r=-0.492, p=0.020)$, and mus- 
cle mass sub-score $(\mathrm{r}=-0.521, \mathrm{p}=0.013)$ of the subjective global assessment. The time-averaged serum bacterial DNA level did not correlate with serum CRP level or arterial PWV (details not shown).

\section{Discussion}

In the present study, we found that using ultrapure dialysate for hemodialysis effectively reduces circulating endotoxin level, but not bacterial DNA level, in hemodialysis patients. It is important to note that previous studies showed that using ultrapure dialysate resulted in a lower dialysate endotoxin level and lower bacterial contamination by standard agar tests $[14,15,17]$. To the best of our knowledge, our study is the first to show that the use of ultrapure dialysate results in a reduction in circulating endotoxin level.

It is important to note that we found an association between circulating endotoxin level and the degree of vascular stiffness and systemic inflammation, and that using ultrapure dialysate for hemodialysis effectively reduces the circulating endotoxin level. However, the serum CRP level continued to increase, albeit not significantly, during the study period and the malnutrition-inflammation score worsened concomitantly. In fact, our data suggest that ultrapure dialysate has no beneficial effect on vascular stiffness or inflammation after the introduction of ultrapure dialysate, and the presence of correlation between circulating endotoxin level and vascular stiffness or markers of systemic inflammation does not necessarily mean any causal relationship. Furthermore, our results on nutrition and inflammatory status are slightly different from published data. Notably, previous studies showed that the switch from conventional to ultrapure dialysate resulted in a lower bacterial contamination by standard agar tests, with a significant decrease of serum CRP and interleukin-6 levels [14, 15, 17]. Schiffl et al. [15] found that the switch from conventional to ultrapure dialysate resulted in significant increases in estimated dry body weight, mid-arm muscle circumference, serum albumin concentration, and protein catabolic rate after 12 months. In contrast, we found that after the switch to ultrapure dialysate for hemodialysis, there remained a continual increase in serum CRP level and malnutrition inflammation score, as well as a decrease in subjective global assessment score and mid-arm circumference. Nonetheless, we did observe that the time-averaged plasma endotoxin level during the study period correlated with the serum CRP level, malnutrition inflam- mation score, and inversely with the serum albumin level, which support the notion that the use of ultrapure dialysate results in lower bacterial contamination and therefore less systemic inflammation. Our results further suggest that in addition to the benefit on inflammation and nutritional status, the use of ultrapure dialysate may have a beneficial effect on the severity of vascular stiffness.

Our results are consistent with the hypothesis that circulating bacterial fragments contribute to the systemic inflammatory state and vascular disease of renal failure patients. Previous studies showed that endotoxin is detectable in the plasma of renal failure and dialysis patients, and the circulating endotoxin level correlates with the severity of systemic inflammation and features of atherosclerosis [24-26]. The results of our present study further showed that there are possible means to reduce the circulating endotoxin level (for example, the use of ultrapure dialysate for hemodialysis), with beneficial effects on nutritional and inflammatory status expected.

We observed that the use of ultrapure dialysate resulted in a reduction of circulating endotoxin but had no distinct effect on the serum bacterial DNA level. The reason for this discrepancy is unknown. Contrary to dialysate endotoxin, circulating bacterial fragments probably derived from the gastrointestinal tract $[15,19]$. In theory, it is possible that when the dialysate has minimal bacterial contamination, circulating endotoxin could be removed like other middle molecules by dialysis, while bacterial DNA fragments may have a substantially higher molecular weight and have no appreciable clearance by conventional dialysis. However, Schindler et al. [27] previously showed that bacterial DNA fragments from dialysate are able to pass through the ultrafiltration membrane and diffuse through high-flux dialyzers. Unfortunately, we did not quantify the bacterial DNA level in the spent dialysate.

In the present study, we did not find that the use of ultrapure dialysate for hemodialysis affects the hemoglobin level or response to the erythropoietin level. Our result is consistent with previous reports by Lamas et al. [28] and Ouseph et al. [29], both of whom found that response to erythropoietin treatment was not improved after the introduction of ultrapure dialysate. In contrast, previous studies showed that the use of pyrogen-free ultrapure dialysate resulted in a better response to recombinant human erythropoietin, which was probably related to the dialysate endotoxin level $[14,16]$. It was possible that the hemoglobin level and the dosage of recombinant human erythropoietin were both relatively low in our patients, 
and the beneficial effect of ultrapure dialysate was therefore not obvious.

There are several inadequacies in our study. First, our sample size was small and there was no control group. It is therefore difficult to judge the effect of our intervention. Furthermore, almost all patients in our study had failed peritoneal dialysis in the past, and many had been on dialysis for an extended period of time (close to 10 years on average). Their vascular disease might be advanced and passed the point of no return, so that the beneficial effect of any intervention may be obscured. In addition, the comprehensive malnutrition-inflammation score and subjective global assessment score are based on similar parameters and may not be considered as independent parameters of the nutritional status. More importantly, many of the correlations that we observed, although statistically significant, are modest from a clinical point of view, suggesting that there are other important determinants of nutrition and inflammation in dialysis patients.

Because of the limitation of our original study design, we did not quantify the bacterial DNA level in the spent dialysate. Throughout the study period, the dialysate endotoxin level was below $0.03 \mathrm{EU} / \mathrm{ml}$, and the bacterial count was below $10 \mathrm{cfu} / \mathrm{ml}$. In addition, we did not determine the effect of ultrapure dialysate on the serum level of middle molecules (for example, $\beta_{2}$-microglobulin). Nonetheless, Furuya et al. [17] previously showed that ultrapure dialysate decreased plasma levels of $\beta_{2}$-mi- croglobulin and pentosidine in hemodialysis patients. Further study is needed to determine the relation between middle molecules and circulating bacterial fragment.

In the present study, the time-averaged endotoxin level correlated with the serum CRP level and pulse wave velocity, while the bacterial DNA level correlated with the nutritional status. Our observation suggests that both circulating endotoxin and bacterial DNA are clinically relevant and they may have different biological effects. This hypothesis would also need to be tested in further studies.

In summary, we found that using ultrapure dialysate for hemodialysis effectively reduces the circulating endotoxin in hemodialysis patients, which is associated with less severe vascular stiffness and systemic inflammation. The causal relationship of this change and the long-term benefit of using ultrapure dialysate require further study.

\section{Acknowledgement}

This study was supported in part by the Richard Yu Chinese University of Hong Kong (CUHK) PD Research Fund, and CUHK research account 6901031.

\section{Disclosure Statement}

The authors declare no other conflict of interest. The results presented in this paper have not been published previously in whole or part, except in abstract format.

\section{References}

1 Weiner DE, Tabatabai S, Tighiouart H, Elsayed E, Bansal N, Griffith J, Salem DN, Levey AS, Sarnak MJ: Cardiovascular outcomes and all-cause mortality: exploring the interaction between CKD and cardiovascular disease. Am J Kidney Dis 2006;48:392-401.

2 Levin A: Clinical epidemiology of cardiovascular disease in chronic kidney disease prior to dialysis. Semin Dial 2003;16:101-105.

- 3 Foley RN, Murray AM, Li S, Herzog CA, McBean AM, Eggers PW, Collins AJ: Chronic kidney disease and the risk for cardiovascular disease, renal replacement, and death in the United States Medicare population, 1998 to 1999. J Am Soc Nephrol 2005;16: 489-495.

4 Parikh NI, Hwang SJ, Larson MG, Meigs JB, Levy D, Fox CS: Cardiovascular disease risk factors in chronic kidney disease: overall burden and rates of treatment and control. Arch Intern Med 2006;166:1884-1891.
5 Sarnak MJ, Levey AS, Schoolwerth AC, Coresh J, Culleton B, Hamm LL, McCullough PA, Kasiske BL, Kelepouris E, Klag MJ, Parfrey P, Pfeffer M, Raij L, Spinosa DJ, Wilson PW: Kidney disease as a risk factor for development of cardiovascular disease: a statement from the American Heart Association Councils on Kidney in Cardiovascular Disease, High Blood Pressure Research, Clinical Cardiology, and Epidemiology and Prevention. Circulation 2003;108:2154-2169.

-6 Ross R: Atherosclerosis: an inflammatory disease. N Engl J Med 1999;340:115-126.

7 Stenvinkel P: Inflammation in end-stage renal failure: could it be treated? Nephrol Dial Transplant 2002;17(suppl 8):S33-S38.

8 Stenvinkel P, Heimburger O, Paultre F, Diczfalusy $\mathrm{U}$, Wang $\mathrm{T}$, Berglund $\mathrm{L}$, Jogestrand T: Strong association between malnutrition, inflammation, and atherosclerosis in chronic renal failure. Kidney Int 1999;55:1899-1911.
9 Owen WF, Lowrie EG: C-reactive protein as an outcome predictor for maintenance hemodialysis patients. Kidney Int 1998;54:627636.

10 Yeun JY, Kaysen GA: Acute phase proteins and peritoneal dialysate albumin loss are the main determinants of serum albumin in peritoneal dialysis patients. Am J Kidney Dis 1997;30:923-927.

11 Szeto CC, Kwan BC, Chow KM, Lai KB, Chung KY, Leung CB, Li PK: Endotoxemia is related to systemic inflammation and atherosclerosis in peritoneal dialysis patients. Clin J Am Soc Nephrol 2008;3:431-436.

-12 McIntyre CW, Harrison LE, Eldehni MT, Jefferies HJ, Szeto CC, John SG, Sigrist MK, Burton JO, Hothi D, Korsheed S, Owen PJ, Lai KB, Li PK: Circulating endotoxemia: a novel factor in systemic inflammation and cardiovascular disease in chronic kidney disease. Clin J Am Soc Nephrol 2011;6:133-141. 
13 Bommer J, Jaber BL: Ultrapure dialysate: facts and myths. Semin Dial 2006;19:115-119.

-14 Sitter T, Bergner A, Schiffl H: Dialysate-related cytokine induction and response to recombinant human erythropoietin in haemodialysis patients. Nephrol Dial Transplant 2000;15: 1207-1211.

15 Schiffl H, Lang SM, Stratakis D, Fischer R: Effects of ultrapure dialysis fluid on nutritional status and inflammatory parameters. Nephrol Dial Transplant 2001;16:1863-1869.

16 Hsu PY, Lin CL, Yu CC, Chien CC, Hsiau TG, Sun TH, Yang CW: Ultrapure dialysate improves iron utilization and erythropoietin response in chronic hemodialysis patients. A prospective cross-over study. J Nephrol 2004; 17:693-700.

17 Furuya R, Kumagai H, Takahashi M, Sano K, Hishida A: Ultrapure dialysate reduces plasma levels of beta 2 -microglobulin and pentosidine in hemodialysis patients. Blood Purif 2005;23:311-316.

18 Glorieux G, Neirynck N, Veys N, Vanholder R: Dialysis water and fluid purity: more than endotoxin. Nephrol Dial Transplant 2012;27: 4010-4021.
19 Bossola M, Sanguinetti M, Scribano D, Zuppi C, Giungi S, Luciani G, Torelli R, Posteraro B, Fadda G, Tazza L: Circulating bacterial-derived DNA fragments and markers of inflammation in chronic hemodialysis patients. Clin J Am Soc Nephrol 2009;4:379-385.

20 Helsel DR. Less than obvious - statistical treatment of data below the detection limit. Environ Sci Technol 1990;24:1766-1774.

21 Enia G, Sicus C, Alati G, Zoccali C: Subjective global assessment of nutrition in dialysis patients. Nephrol Dial Transplant 1993;8:10941098.

22 Cheng TH, Lam DH, Ting SK, Wong CL, Kwan BC, Chow KM, Law MC, Li PK, Szeto CC: Serial monitoring of nutritional status in Chinese peritoneal dialysis patients by Subjective Global Assessment and comprehensive Malnutrition Inflammation Score. Nephrology (Carlton) 2009;14:143-147.

23 Szeto CC, Kwan BC, Chow KM, Leung CB, Law MC, Li PK: Prognostic value of arterial pulse wave velocity in peritoneal dialysis patients. Am J Nephrol 2012;35:127-133.

24 Werner N, Kosiol S, Schiegl T, Ahlers P, Walenta K, Link A, Bohm M, Nickenig G: Circulating endothelial progenitor cells and cardiovascular outcomes. N Engl J Med 2005; 353:999-1007.
25 de Almeida Duarte JB, de Aguilar-Nascimento JE, Nascimento M, Nochi RJ Jr: Bacterial translocation in experimental uremia. Urol Res 2004;32:266-270.

26 Selgas R, Bajo MA, Jimenez C, Sanchez C, Del Peso G, Cacho G, Diaz C, Fernandez-Reyes MJ, De Alvaro F: Peritoneal dialysis in liver disorders. Perit Dial Int 1996;16(suppl 1): S215-S219.

27 Schindler R, Beck W, Deppisch R, Aussieker M, Wilde A, Göhl H, Frei U: Short bacterial DNA fragments: detection in dialysate and induction of cytokines. J Am Soc Nephrol 2004; 15:3207-3214

28 Lamas JM, Alonso M, Sastre F, García-Trío G, Saavedra J, Palomares L: Ultrapure dialysate and inflammatory response in haemodialysis evaluated by darbepoetin requirements - a randomized study. Nephrol Dial Transplant 2006;21:2851-2858.

29 Ouseph R, Jones S, Dhananjaya N, Ward RA: Use of ultrafiltered dialysate is associated with improvements in haemodialysis-associated morbidity in patients treated with reused dialysers. Nephrol Dial Transplant 2007;22: 2269-2275. 